\title{
Determinants of Accident Status on Student Commuters of Jabodetabek in 2019
}

\author{
Determinan Status Kecelakaan pada Komuter Pelajar Jabodetabek \\ Tahun 2019
}

\author{
Aprilia Lutviana Dewi ${ }^{1 *}$, Budyanra ${ }^{2 *}$
}

\begin{abstract}
Traffic accidents among students are one of the problems experienced in the Greater Jakarta area. World Health Organization (WHO) stated that younger drivers are the most vulnerable group to experiencing traffic accidents, including the students. According to Badan Pusat Statistik (BPS), it was estimated that as many as 301,120 Jabodetabek commuters had experienced a traffic accident in 2019. Moreover, 13 to 14 out of the 100 commuters who had experienced traffic accidents are student commuters or commuters with the main activities going to school. Therefore, this study was conducted to determine the factors that affect the accident status of Jabodetabek student commuters in 2019 and their odds ratios by using the 2019 Jabodetabek Commuter Survey data. The analytical method used is a binary logistic regression with the parameter estimation method using penalized maximum likelihood estimation (PMLE). And the results showed that the variables of age, gender, last education, mode of transportation, classification of the area of residence, distance traveled, and the area of the activity had a significant influence on the accident status of Jabodetabek student commuters. Furthermore, student commuters who live in rural areas have the highest tendency to experience a traffic accident.
\end{abstract}

Keywords: traffic accident, student commuter, binary logistic regression, PMLE, Jabodetabek

\begin{abstract}
Abstrak
Kecelakaan lalu lintas pada pelajar merupakan salah satu permasalahan yang dialami wilayah Jabodetabek. WHO menyatakan bahwa kecelakaan lalu lintas rentan dialami pengendara muda, termasuk pelajar. Menurut BPS, diperkirakan sebanyak 301.120 komuter Jabodetabek pernah mengalami kecelakaan lalu lintas pada tahun 2019. Terlebih, sebanyak 13 hingga 14 dari 100 komuter yang pernah mengalami kecelakaan tersebut merupakan komuter pelajar atau komuter dengan kegiatan utama bersekolah. Oleh sebab itu, penelitian ini bertujuan untuk mengetahui gambaran umum karakteristik komuter pelajar Jabodetabek dan mengetahui determinan apa saja yang dapat memengaruhi status kecelakaan pada komuter pelajar Jabodetabek Tahun 2019 serta kecenderungannya menggunakan raw data hasil Survei Komuter Jabodetabek 2019. Metode
\end{abstract}

${ }^{*}$ Politeknik Statistika STIS,

Email Address: ${ }^{1} 211709566 @$ stis.ac.id, ${ }^{2}$ budy@stis.ac.id

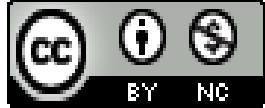

This work is licensed under a Creative Commons Attribution-NonCommercial 4.0 International License 


\section{Jurnal Matematika, Statistika \& Komputasi Aprilia Lutviana Dewi, Budyanra}

analisis yang digunakan adalah regresi logistik biner dengan metode estimasi parameternya menggunakan metode PMLE. Dan hasil penelitian menunjukkan bahwa variabel umur, jenis kelamin, pendidikan terakhir, moda transportasi, klasifikasi wilayah tempat tinggal, jarak tempuh, dan wilayah kegiatan memberikan pengaruh yang signifikan terhadap status kecelakaan komuter pelajar Jabodetabek. Selanjutnya, komuter pelajar Jabodetabek yang tinggal di wilayah perdesaan memiliki kecenderungan paling tinggi untuk mengalami kecelakaan lalu lintas.

Kata kunci: kecelakaan lalu lintas, komuter pelajar, regresi logistik biner, PMLE, Jabodetabek

\section{PENDAHULUAN}

Mobilitas merupakan salah satu hal yang memiliki peran penting dalam kehidupan manusia di masa modern. Namun, hingga kini mobilitas masih dihadapi oleh masalah keamanan. Menurut WHO, sekitar 1,35 juta orang meninggal akibat kecelakaan lalu lintas setiap tahunnya [41]. Dalam temuannya, WHO menyebutkan bahwa 93\% korban jiwa akibat kecelakaan lalu lintas tersebut berasal dari negara berpendapatan rendah hingga menengah dan rentan terjadi di kalangan pengendara muda, terutama pada jenis kelamin laki-laki. Sebagai salah satu negara dengan pendapatan menengah, Indonesia belum mampu terlepas dari permasalahan kecelakaan lalu lintas dari tahun ke tahun, khususnya kecelakaan lalu lintas di kalangan pelajar. ASEAN Stats Data Portal mengestimasi Indonesia menjadi negara dengan korban kecelakaan lalu lintas terbanyak di ASEAN mencapai 134,35 ribu korban pada tahun 2017 [4]. Direktorat Penegakkan Hukum Korps Lalu Lintas Polri juga mencatat bahwa terjadi peningkatan jumlah kejadian kecelakaan lalu lintas di Indonesia dari tahun 2017 hingga tahun 2019. Kecelakaan lalu lintas yang melibatkan pelajar dan mahasiswa berkontribusi tinggi terhadap total kejadian kecelakaan lalu lintas yang terjadi di Indonesia. Kejadian kecelakaan pelajar mencapai 39.940 kasus atau 39,53\% dari total kecelakaan yang terjadi pada tahun 2017. Lalu angka tersebut meningkat pada tahun 2018 menjadi 41.879 kasus (40,39\%) dan kembali meningkat pada tahun 2019 menjadi 71.134 kasus $(61,11 \%)$ [15, 33].

Kecelakaan kerap terjadi di wilayah metropolitan serta di wilayah dengan kepadatan lalu lintas yang tinggi [22]. Wilayah metropolitan yang memiliki kepadatan lalu lintas tertinggi di Indonesia adalah Jabodetabek (Jakarta, Bogor, Depok, Tangerang, dan Bekasi) dengan rata-rata waktu tempuh mencapai 90 menit [39]. Berdasarkan data Statistik Komuter Jabodetabek 2019, terdapat 3.259.894 penduduk Jabodetabek berstatus komuter yang melakukan mobilitas ulang-alik atau perjalanan pulang-pergi pada hari yang sama, dan 626.933 di antaranya merupakan komuter pelajar, yaitu komuter yang memiliki kegiatan utama belajar. Pada tahun 2019, diperkirakan sebanyak 301.120 atau sebesar 9,2\% dari total komuter Jabodetabek pernah mengalami kecelakaan lalu lintas dan 41.183 di antaranya merupakan komuter pelajar [6].

Kecelakaan lalu lintas dapat disebabkan oleh tiga faktor, yaitu faktor manusia, faktor kendaraan, dan faktor lingkungan [14]. Faktor eksternal berperan penting dalam mengurangi resiko kecelakaan lalu lintas. Faktor eksternal tersebut di antaranya meliputi kondisi jalan, penggunaan transportasi umum, dan penggunaan kendaraan motor [36]. Secara umum, kondisi jalan di seluruh wilayah Jabodetabek sudah relatif baik pada tahun 2019. Persentase panjang jalan dengan kondisi baik di masing-masing wilayah kabupaten/kota sudah mencapai lebih dari $75 \%$ dari total panjang jalan di masing-masing wilayah kabupaten/kota [7, 8, 33]. Jika dikaji dari segi transportasi yang digunakan oleh komuter untuk pergi menuju tempat kegiatan, sebanyak 63 hingga 64 dari 100 komuter Jabodetabek menggunakan motor dan 16 hingga 17 dari 100 komuter 


\section{Jumal Matematika, Statistika E Komputasi Aprilia Lutviana Dewi, Budyanra}

Jabodetabek menggunakan transportasi umum [6]. Meskipun faktor eksternal memiliki peran yang penting dalam kecelakaan lalu lintas, faktor internal atau faktor manusia merupakan faktor yang sangat berkontribusi dalam kecelakaan lalu lintas [36]. Faktor ini dapat dikaji dari tingkat pendidikan, umur, dan jenis kelamin. Tingkat pendidikan merupakan faktor terpenting yang memiliki pengaruh besar dalam kecelakaan lalu lintas [33]. Sebanyak 80 hingga 81 dari 100 komuter Jabodetabek memiliki pendidikan tertinggi yang ditamatkan minimal di tingkat SMA sederajat [6].

Kondisi-kondisi yang dijelaskan di atas idealnya seharusnya sudah mendukung pencegahan terjadinya kecelakaan lalu lintas pada komuter Jabodetabek, khususnya pada komuter pelajar. Oleh sebab itu, gambaran umum karakteristik dan determinan status kecelakaan pada komuter pelajar Jabodetabek perlu diketahui. Berdasarkan latar belakang yang sudah dijelaskan, tujuan penelitian ini adalah untuk mengetahui gambaran umum karakteristik komuter pelajar Jabodetabek tahun 2019, mengetahui variabel-variabel yang memengaruhi status kecelakaan komuter pelajar Jabodetabek tahun 2019, dan mengetahui kecenderungan variabel yang signifikan memengaruhi status kecelakaan pada komuter pelajar Jabodetabek tahun 2019.

Beberapa penelitian mengenai kecelakaan lalu lintas pada pelajar/remaja di Indonesia sudah pernah dilakukan. Penelitian yang dilakukan oleh Ratnasari dkk. (2014) yang melakukan studi kasus pada Komunitas Motor Sulut King Manado menyatakan bahwa terdapat hubungan antara jenis kelamin, faktor sosial ekonomi, waktu kejadian, dan kecepatan berkendara dengan kejadian kecelakaan lalu lintas [32]. Selanjutnya, penelitian yang dilakukan oleh Setyowati dkk. (2018) di sembilan sekolah menengah atas (SMA) di Kota Samarinda menunjukkan bahwa terdapat hubungan antara faktor manusia (perilaku berkendara) dan kejadian kecelakaan lalu lintas [35]. Penelitian lainnya dilakukan oleh Gigy dkk. (2019) yang melakukan studi kasus di tiga sekolah menengah atas di Kota Kupang menyatakan bahwa faktor manusia (perilaku berkendara) dan faktor lingkungan memiliki hubungan dengan kejadian kecelakaan lalu lintas [13]. Akan tetapi, penelitian-penelitian tersebut masih berupa studi kasus pada sekolah atau komunitas tertentu saja, sehingga cakupan wilayah yang digunakan juga masih sangat terbatas. Selanjutnya, penelitian tersebut juga hanya membahas hubungan variabel, sehingga belum membahas kecenderungan dari masing-masing variabel yang memengaruhi kecelakaan lalu lintas pada pelajar.

\section{TINJAUAN PUSTAKA}

\section{a) Mobilitas}

Mobilitas penduduk merupakan proses perpindahan penduduk yang dilakukan dengan melewati batas wilayah tertentu dan dalam jangka waktu tertentu [23]. Menurut Mantra, mobilitas penduduk terdiri atas mobilitas vertikal dan mobilitas horizontal. Mobilitas vertikal umumnya diartikan sebagai perubahan status sosial seseorang, misalnya status pekerjaan. Sementara mobilitas horizontal diartikan sebagai perpindahan penduduk secara geografis yang dilakukan dari suatu wilayah ke wilayah lainnya dalam jangka waktu tertentu. Bila mengacu pada konsep yang digunakan oleh Badan Pusat Statistik (BPS), batas wilayah yang digunakan adalah provinsi dan batas waktu yang digunakan adalah enam bulan atau lebih [5].

Mobilitas horizontal terbagi atas mobilitas permanen dan mobilitas nonpermanen [23]. Mobilitas permanen (migrasi) merupakan mobilitas yang dilakukan oleh penduduk dengan niat menetap. Sedangkan mobilitas nonpermanen merupakan mobilitas yang dilakukan oleh penduduk tanpa adanya niat menetap [23]. Mobilitas permanen terdiri atas migrasi seumur hidup dan migrasi risen. Sedangkan mobilitas nonpermanen terdiri atas mobilitas ulang-alik dan mobilitas sirkuler. 


\section{Jumal Matematika, Statistika E Komputasi Aprilia Lutviana Dewi, Budyanra}

\section{b) Mobilitas Ulang-Alik}

Mobilitas ulang-alik, yang disebut juga sebagai commuting atau nglaju, didefinisikan sebagai proses perpindahan penduduk yang dilakukan secara rutin dari wilayah asal menuju wilayah tujuan dalam jangka waktu terbatas dan kembali ke wilayah asal pada hari yang sama [23]. Seseorang yang melakukan mobilitas ulang-alik disebut sebagai komuter. Hugo (1975) membagi mobilitas ulang-alik menjadi dua jenis, yaitu autochthonous commuter dan allochthonous commuter [17]. Autochthonous commuter merupakan komuter yang berasal dari wilayah pinggiran kota yang melakukan mobilitas ulang-alik ke wilayah pusat kota dengan dorongan faktor ekonomi, misalnya pekerjaan. Sementara itu, allochthonous commuter merupakan komuter yang berasal dari wilayah pusat kota yang melakukan mobilitas ulang-alik karena keputusannya untuk berpindah ke wilayah pinggiran kota untuk memperoleh tempat tinggal. Keuntungan yang dapat diperoleh dari melakukan mobilitas ulang-alik adalah banyaknya kesempatan pekerjaan dan ketersediaan fasilitas pendidikan [17]. Menurut Hugo, fasilitas pendidikan yang lebih baik di wilayah tujuan mendorong pelajar untuk melakukan mobilitas ulang-alik.

Dalam melakukan kegiatan mobilitas setiap harinya, komuter tidak terlepas dari berbagai macam risiko gangguan kesehatan (batuk/pilek, demam, sakit kepala, sakit mata, sakit tenggorokan, sesak napas/asma, pegal-pegal, masuk angin, dan stres akibat perjalanan) maupun risiko gangguan perjalanan (kecelakaan, kemacetan parah, tindak kejahatan, gangguan pada moda transportasi, dan pelecehan seksual) [6]. Di antara berbagai keluhan kesehatan dan gangguan dalam perjalanan yang rentan dialami oleh komuter, kecelakaan merupakan jenis gangguan paling berbahaya. Sebanyak $24 \%$ dari total 5 juta orang di dunia (yang mengalami cedera) meninggal akibat cedera yang disebabkan kecelakaan lalu lintas [40]. Selain itu, kecelakaan lalu lintas juga merupakan penyebab utama kematian pada anak-anak dan pemuda berusia 5-29 tahun [38]. Kepolisian Republik Indonesia menyatakan bahwa rata-rata 3 orang meninggal setiap jam akibat kecelakaan lalu lintas di Indonesia [19].

\section{c) Kecelakaan Lalu Lintas}

Kecelakaan lalu lintas adalah suatu peristiwa yang terjadi secara tidak disengaja dan tidak diduga yang terjadi di jalan serta melibatkan kendaraan dengan/tanpa pengguna jalan lain sehingga mengakibatkan korban manusia dan/atau kerugian harta benda [38]. Haddon menyebutkan bahwa kecelakaan lalu lintas dapat disebabkan oleh faktor lingkungan, faktor kendaraan, dan faktor manusia [14]. Faktor-faktor tersebut di antaranya meliputi umur [25, 32], jenis kelamin [9, 25], pendidikan terakhir [26, 33], moda transportasi [21], klasifikasi wilayah tempat tinggal [1, 37], jarak tempuh [3,10], wilayah kegiatan [11].

Umur merupakan lama hidup komuter pelajar berdasarkan ulang tahun terakhir [6]. Hasil penelitian terdahulu menyatakan bahwa kecelakaan pada pengendara berumur kurang dari 16 tahun dan 16-19 tahun merupakan masalah yang serius [25, 32]. Selanjutnya, jenis kelamin merupakan pembeda antara komuter pelajar laki-laki dan perempuan [6]. Dalam hal kecelakaan, laki-laki memiliki kecenderungan lebih tinggi untuk mengalami kecelakaan dibandingkan perempuan $[9,25]$. Kemudian pendidikan terakhir merupakan jenjang pendidikan yang sedang diduduki oleh komuter pelajar [6]. Hasil penelitian terdahulu menunjukkan bahwa pengendara dengan pendidikan SMP ke bawah memiliki tingkat keparahan dan kematian akibat kecelakaan lalu lintas yang tinggi [26, 33]. Moda transportasi merupakan alat transportasi utama yang biasa digunakan oleh komuter pelajar menuju tempat kegiatan dengan jarak terjauh atau waktu paling lama [6]. Penelitian terdahulu menunjukkan bahwa transportasi umum memiliki tingkat kecelakaan lalu lintas lebih rendah dibandingkan transportasi pribadi [21]. Berikutnya, klasifikasi 


\section{Jurnal Matematika, Statistika \& Komputasi}

\section{Aprilia Lutviana Dewi, Budyanra}

wilayah tempat tinggal merupakan pengklasifikasian desa/kelurahan tempat tinggal komuter pelajar dengan status perkotaan atau perdesaan [6]. Hasil penelitian terdahulu menunjukkan bahwa kecelakaan lalu lintas yang terjadi di wilayah perdesaan memiliki tingkat keparahan lebih tinggi dibandingkan di wilayah perkotaan $[1,37]$. Sementara itu, jarak tempuh merupakan jarak sekali perjalanan yang ditempuh oleh komuter pelajar dari rumah sampai ke tempat kegiatan [6]. Jarak tempuh lebih dari $10 \mathrm{~km}$ dapat menyebabkan kelelahan dan kantuk, sehingga dapat meningkatkan kecenderungan terjadinya kecelakaan [3, 10]. Terakhir, wilayah kegiatan merupakan wilayah kabupaten/kota tempat komuter pelajar menjalani kegiatan (bersekolah) [6]. Dalam penelitian ini, wilayah kegiatan dikelompokkan menjadi tiga, yaitu Jakarta, Detabek (Kota Depok, Kota Tangerang, Kota Tangerang Selatan, Kabupaten Tangerang, Kota Bekasi, dan Kabupaten Bekasi), dan Bogor (Kabupaten Bogor dan Kota Bogor) karena perbedaan karakteristik di antara ketiga wilayah tersebut. Jakarta merupakan kota inti Jabodetabek [32]. Sementara Detabek merupakan kota satelit Jabodetabek yang berbatasan langsung dengan Jakarta dan Bogor merupakan kota satelit yang tidak berbatasan langsung dengan Jakarta. Wilayah Bogor dijuluki sebagai "kota hujan" karena memiliki intensitas hujan yang tinggi, sehingga memiliki resiko lebih tinggi terhadap kejadian kecelakaan [24, 28]. Sementara Jakarta merupakan pusat kegiatan ekonomi reginonal, nasional, dan internasional, sehingga wilayah Jakarta juga cukup berisiko terhadap kecelakaan akibat padatnya aktivitas di wilayah tersebut [31]. Eurostat mengatakan bahwa perbedaan karakteristik antar wilayah dapat menghasilkan resiko kecelakaan lalu lintas yang berbeda [11].

\section{d) Regresi Logistik Biner}

Analisis regresi logistik biner adalah analisis regresi logistik yang digunakan ketika variabel respons penelitian bersifat dikotomi dimana kategori dalam variabel respons tersebut memiliki kode 1 dan 0 [2]. Agresti mengatakan bahwa dalam metode regresi logistik biner, variabel respons (Y) mengikuti distribusi Bernoulli. Oleh sebab itu, fungsi likelihood dari model regresi logistik biner yang terbentuk adalah sebagai berikut [16]:

$$
f\left(y_{i}, \pi\left(x_{i}\right)\right)=\prod_{i=1}^{n} \pi\left(x_{i}\right){ }^{\Re}\left[1-\pi\left(x_{i}\right)\right]^{\left(1-y_{i}\right)}, y=0,1
$$

dimana:

$\pi\left(x_{i}\right)$ peluang kejadian sukses

$y_{i} \quad$ nilai variabel respons

Adapun model regresi logistik biner ditulis sebagai berikut [16]:

$$
\pi(x)=\frac{e^{\beta_{0}+\beta_{1} x_{1}+\cdots+\beta_{p} x_{p}}}{1+e^{\beta_{0}+\beta_{1} x_{1}+\cdots+\beta_{p} x_{p}}}
$$

dimana:

$$
\begin{array}{ll}
\pi(x) & \begin{array}{l}
\text { fungsi nonlinear yang menggambarkan peluang kejadian sukses dengan nilai } 0 \\
\text { hingga } 1
\end{array} \\
\beta & \text { parameter model } \\
p & \text { jumlah variabel predictor }
\end{array}
$$

Sebagai fungsi non-linear, perlu dilakukan transformasi terhadap $\pi(x)$ untuk memudahkan proses pendugaan parameter. Transformasi dilakukan dengan menggunakan transformasi logit, sehingga menghasilkan persamaan sebagai berikut: 


\section{Jurnal Matematika, Statistika \& Komputasi}

\section{Aprilia Lutviana Dewi, Budyanra}

$$
g(x)=\ln \left(\frac{\pi(x)}{1-\pi(x)}\right)=\beta_{0}+\beta_{1} x_{1}+\cdots+\beta_{p} x_{p}
$$

Metode estimasi yang digunakan untuk melakukan estimasi parameter dalam model regresi logistik biner adalah maximum likelihood estimation (MLE). Menurut Hosmer dan Lemeshow, metode MLE adalah metode yang dilakukan dengan memaksimalkan peluang dari data amatan yang diperoleh dengan menggunakan sebuah fungsi likelihood [16]. Namun, proses estimasi model regresi logistik menggunakan metode MLE akan menjadi bias bila diterapkan pada penelitian mengenai kejadian langka, sehingga diperlukan metode estimasi parameter lain yang dapat menangani bias tersebut [20].

\section{e) Estimasi Parameter PMLE}

Kejadian langka atau rare events merupakan kondisi di mana proporsi kejadian sukses ( $\mathrm{Y}=1)$ jauh lebih kecil dibandingkan bukan kejadian sukses ( $\mathrm{Y}=0)$ [20]. King dan Zeng mengatakan bahwa suatu kejadian dapat dikategorikan sebagai kejadian langka apabila kejadian sukses lusinan atau ribuan kali lebih kecil jumlahnya dibandingkan yang bukan kejadian sukses [20]. Firth mengusulkan metode estimasi yang disebut dengan penalized maximum likelihood estimation (PMLE) [12]. Metode ini berfungsi untuk mengoreksi bias yang dihasilkan oleh pendugaan parameter menggunakan metode MLE akibat sampel kecil, rare events, dan adanya pemisahan [18]. Fungsi penalized likelihood dari metode Firth ditunjukkan dalam persamaan berikut [12].

$$
l^{*}(\boldsymbol{\beta})=l(\boldsymbol{\beta})|\boldsymbol{i}(\boldsymbol{\beta})|^{\frac{1}{2}}
$$

Sedangkan fungsi log likelihood yang diperoleh dari persamaan di atas adalah sebagai berikut:

$$
L^{*}(\boldsymbol{\beta})=\ln [l(\boldsymbol{\beta})]+\frac{1}{2} \ln [|\boldsymbol{i}(\boldsymbol{\beta})|]
$$

dimana:

$l(\boldsymbol{\beta})=$ fungsi likelihood dari metode MLE, $\prod_{i=1}^{n} \pi\left(x_{i}\right)^{y i}\left[1-\pi\left(x_{i}\right)\right]^{\left(1-y_{i}\right)}, y=0,1$

$\ln [l(\boldsymbol{\beta})$ 月 fungsi log likelihood dari metode MLE

$\left[\left.\boldsymbol{i}(\boldsymbol{\beta})\right|^{\frac{1}{2}}=\right.$ Jeffrey's invariant prior

Dasar dari metode Firth adalah mengurangi bias pada penduga parameter dengan memasukkan bias yang kecil pada score function [12]. Modifikasi terhadap score function ditunjukkan dalam Gambar (2.1). 


\section{Jumal Matematika, Statistika E Komputasi}

\section{Aprilia Lutviana Dewi, Budyanra}

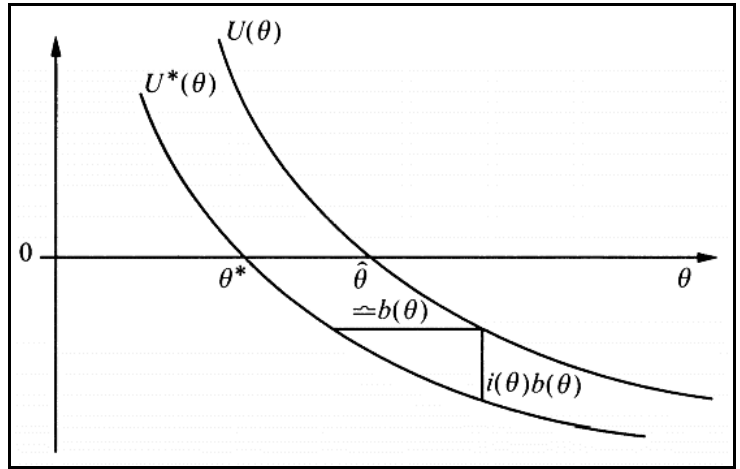

Gambar 1. Modifikasi unbiased score function pada metode Firth

Apabila penduga parameter memiliki bias positif, maka score function $U(\beta)$ akan bergeser ke bawah pada masing-masing titik parameter sebesar $i(\beta) b(\beta)$ [12]. Persamaan berikut menunjukan persamaan modifikasi score function.

$$
U^{*}(\boldsymbol{\beta})=U(\boldsymbol{\beta})-\boldsymbol{i}(\boldsymbol{\beta}) \boldsymbol{b}(\boldsymbol{\beta})
$$

dimana:

$$
\begin{aligned}
& U(\boldsymbol{\beta})=\text { score function dari MLE, } U(\boldsymbol{\beta})=\left[\begin{array}{l}
U(\boldsymbol{\beta})_{\beta_{0}} \\
U(\boldsymbol{\beta})_{\beta}
\end{array}\right]=\left[\begin{array}{l}
\frac{\partial L(\beta)}{\partial\left(\beta_{0}\right)} \\
\frac{\partial L(\beta)}{\partial(\beta)}
\end{array}\right]=\left[\begin{array}{c}
\sum_{i=1}^{n}\left[y_{i}-\pi\left(x_{i}\right)\right] \\
\sum_{i=1}^{n} x_{i}\left[y_{i}-\pi\left(x_{i}\right)\right]
\end{array}\right] \\
& i(\boldsymbol{\beta})=\text { Fisher infomration matrix, } i(\boldsymbol{\beta})=\left[\begin{array}{cc}
-E\left(\frac{\partial^{\mathrm{x}} L(\beta)}{\partial\left(\beta_{0}{ }^{2}\right)}\right) & -E\left(\frac{\partial^{\mathrm{x}} L(\beta)}{\partial\left(\beta_{0}\right) \partial\left(\beta_{1}\right)}\right) \\
-E\left(\frac{\partial^{\mathrm{z}} L(\beta)}{\partial\left(\beta_{0}\right) \partial\left(\beta_{1}\right)}\right) & -E\left(\frac{\partial^{\mathrm{x}} L(\beta)}{\partial\left(\beta_{1}{ }^{2}\right)}\right)
\end{array}\right] \\
& b(\boldsymbol{\beta})=\quad \text { bias } O\left(n^{-1}\right) \text { dari penduga parameter MLE }
\end{aligned}
$$

Penduga parameter $\hat{\beta}$ dengan metode PMLE dapat diperoleh menggunakan metode Fisher scoring dengan score function termodifikasi seperti pada Persamaan (6). Dengan adanya modifikasi score function $U^{*}(\boldsymbol{\beta})$ dalam setiap langkahnya, kandidat penduga MLE pada iterasi berikutnya dikoreksi dengan mengurangi bias $O\left(n^{-1}\right)$ dari penduga tersebut seperti pada Persamaan (7).

$$
\begin{aligned}
& \beta^{(t+1)}=\beta^{(t)}+\left(i(\beta)^{(t)}\right)^{-1} U\left(\beta^{(t)}\right)^{*} \\
& \quad=\beta^{(t)}-b(\beta)^{(t)}+\left(i(\beta)^{(t)}\right)^{-1} U\left(\beta^{(t)}\right)
\end{aligned}
$$

\section{f) Uji Hosmer-Lemeshow}

Uji Hosmer-Lemeshow adalah salah satu pengujian yang dilakukan untuk memeriksa apakah model yang diperoleh sudah efektif untuk menjelaskan variabel respons [16]. Hosmer dan Lemeshow mengatakan bahwa kondisi tersebut tercapai apabila model telah berisi variabelvariabel yang idealnya masuk ke dalam model dan variabel-variabel tersebut telah dimasukkan dengan bentuk fungsional yang benar. Statistik uji Hosmer-Lemeshow $(\widetilde{\bar{C}})$ diperoleh melalui 


\section{Jumal Matematika, Statistika \& Komputasi}

\section{Aprilia Lutviana Dewi, Budyanra}

penghitungan nilai Pearson chi-square tabel $g \times 2$ dari frekuensi observasi dan estimasi frekuensi harapan. Rumus yang digunakan untuk menghitung nilai $\hat{C}$ adalah sebagai berikut:

$$
\hat{C}=\sum_{k=1}^{g} \frac{\left(o_{k}-n_{k}^{g} \bar{\pi}_{k}\right)^{2}}{n_{k}^{\prime} \bar{\pi}_{k}\left(1-\bar{\pi}_{k}\right)}
$$

dimana:

$$
\begin{array}{ll}
o_{k} & \text { jumlah nilai variabel respons, } o_{k}=\sum_{j=1}^{c_{k}} y_{j} . \\
c_{k} & \text { jumlah kombinasi variabel prediktor pada desil ke-k. } \\
\bar{\pi}_{k} & \text { rata-rata estimasi probability dalam desil ke- } k, \bar{\pi}_{k}=\sum_{j=1}^{c_{k}} \frac{m_{j} \hat{\pi}_{j}}{n_{k}^{l}} \\
n_{k}^{\prime} & \text { jumlah subjek dalam desil ke- } k . \\
g & \text { jumlah grup (desil). }
\end{array}
$$

Hipotesis nol $\left(H_{0}\right)$ dari uji Hosmer-Lemeshow adalah model yang terbentuk sudah sesuai. Statistik uji Hosmer-Lemeshow mengikuti distribusi peluang chi-square dengan degrees of freedom sebesar g-2 $\left(\chi_{(g-2)}^{2}\right)$. Oleh sebab itu, keputusan gagal tolak $H_{0}$ diperoleh saat statistik uji $\widehat{C}$ bernilai lebih kecil daripada nilai chi-square tabel $\chi_{\alpha(g-2)}^{2}$ atau saat nilai $p$-value lebih besar dari nilai $\alpha$.

\section{g) Uji Likelihood Ratio}

Uji likelihood ratio adalah uji parameter yang dilakukan untuk mengetahui pengaruh seluruh variabel prediktor secara serentak (simultan) terhadap variabel respons [16]. Statistik uji likelihood ratio $(G)$ diperoleh melalui penghitungan dengan rumus seperti berikut:

$$
G=-2 \ln \left[\frac{L_{0}}{L_{1}}\right]
$$

dimana:

$L_{0} \quad$ nilai likelihood dari model tanpa variabel prediktor.

$L_{1} \quad$ nilai likelihood dari model dengan variabel prediktor.

Hipotesis nol $\left(H_{0}\right)$ dari uji likelihood ratio adalah $\beta_{1}=\beta_{2}=\cdots=\beta_{p}=0$ atau tidak terdapat pengaruh yang signifikan antara seluruh variabel prediktor secara simultan terhadap variabel respons. Statistik uji likelihood ratio mengikuti distribusi peluang chi-square dengan degrees of freedom sebesar $p\left(\chi_{(p)}^{2}\right)$ dimana $p$ merupakan selisih jumlah parameter pada model dengan variabel prediktor dan model tanpa variabel prediktor. Oleh sebab itu, keputusan tolak $H_{0}$ diperoleh saat statistik uji $G$ bernilai lebih dari sama dengan nilai chi-square tabel $\chi_{\alpha(p)}^{2}$ atau ketika nilai $p$-value lebih kecil sama dengan nilai $\alpha$.

\section{h) Uji Wald}

Uji Wald adalah pengujian parameter yang dilakukan untuk mengetahui variabel prediktor mana yang berpengaruh signifikan terhadap variabel respons secara parsial [16]. Uji ini dilakukan setelah uji simultan apabila pada uji simultan diperoleh keputusan tolak $H_{0}$. Statistik uji Wald $(W)$ diperoleh melalui penghitungan dengan rumus seperti berikut: 


\section{Jurnal Matematika, Statistika \& Komputasi}

\section{Aprilia Lutviana Dewi, Budyanra}

$$
W=\left[\frac{\widehat{\beta_{j}}}{S E\left(\widehat{\beta}_{j}\right)}\right]^{2}
$$

dimana:

$\widehat{\beta_{j}} \quad$ nilai penduga parameter ke- $j$.

$S E\left(\widehat{\beta}_{j}\right) \quad$ nilai standard error penduga parameter ke-j.

$j \quad 1,2, \ldots, p$ dimana $p$ merupakan jumlah variabel prediktor.

Hipotesis nol $\left(H_{0}\right)$ dari uji Wald adalah $\beta_{j}=0$ atau tidak terdapat pengaruh yang signifikan antara variabel prediktor ke- $j$ terhadap variabel respons. Statistik uji Wald mengikuti distribusi peluang chi-square dengan derajat bebas sebesar $1\left(\chi_{(1)}^{2}\right)$. Oleh sebab itu, keputusan tolak $H_{0}$ diperoleh saat nilai $W$ lebih dari sama dengan nilai $\chi_{\alpha(1)}^{2}$ atau ketika nilai $p$-value lebih kecil sama dengan nilai $\alpha$.

\section{i) Rasio Kecenderungan (Odds Ratio)}

Rasio kecenderungan (odds ratio) merupakan ukuran tingkat risiko yang digambarkan dengan perbandingan antara dua kejadian yang didefinisikan sebagai kategori sukses atau gagal [16]. Hosmer dan Lemeshow menyatakan bahwa nilai odds ratio dapat diperoleh dengan rumus sebagai berikut:

$$
O R=e^{\beta_{j}}
$$

dimana $\beta_{j}$ merupakan nilai parameter model ke- $j$. $O R$ bersifat nonnegatif dengan nilai $O R$ lebih dari satu akan menjelaskan bahwa variabel prediktor dengan kategori $x=1$ memiliki kecenderungan sebesar $O R$ untuk mengalami kejadian $y=1$ dibandingkan $x=0$ [2]. Sementara nilai $O R$ kurang dari satu menunjukkan bahwa variabel prediktor dengan kategori $x=0$ memiliki kecenderungan sebesar 1/OR untuk mengalami kejadian $y=1$ dibandingkan $x=1$.

\section{METODE PENELITIAN}

\subsection{Sumber Data dan Variabel Penelitian}

Penelitian ini menggunakan data sekunder yang berasal dari Survei Komuter Jabodetabek tahun 2019 yang diselenggarakan oleh BPS terhadap penduduk berumur lima tahun ke atas di wilayah Jabodetabek meliputi wilayah Kota Jakarta Pusat, Kota Jakarta Utara, Kota Jakarta Timur, Kota Jakarta Selatan, Kota Jakarta Barat, Kota Bogor, Kabupaten Bogor, Kota Depok, Kota Tangerang, Kota Tangerang Selatan, Kabupaten Tangerang, Kota Bekasi, dan Kabupaten Bekasi dengan metode two stage sampling. Unit analisis penelitian adalah penduduk Jabodetabek berumur lima tahun ke atas yang berstatus komuter dan memiliki kegiatan utama bersekolah di wilayah Jabodetabek dari jenjang sekolah dasar (SD) hingga strata 3 (S3).

Variabel respons yang digunakan dalam penelitian merupakan status kecelakaan komuter pelajar Jabodetabek tahun 2019 yang bersifat kategorik. Variabel respons terdiri atas dua kategori, yaitu pernah mengalami kecelakaan dan tidak pernah mengalami kecelakaan. Sedangkan variabel prediktor yang penelitian ini terdiri dari variabel umur komuter pelajar, jenis kelamin komuter pelajar, pendidikan terakhir komuter pelajar, moda transportasi komuter pelajar, klasifikasi wilayah tempat tinggal, jarak tempuh komuter pelajar, dan wilayah kegiatan komuter pelajar. Seluruh variabel prediktor yang digunakan bersifat kategorik. 


\section{Jumal Matematika, Statistika \& Komputasi}

\section{Aprilia Lutviana Dewi, Budyanra}

\subsection{Metode Analisis}

Metode analisis deskriptif dan analisis inferensia digunakan untuk menjawab tujuan penelitian. Analisis dilakukan menggunakan software $R$ version 4.0.3 dan QGIS version 3.10.2. Analisis deskriptif dalam penelitian ini ditampilkan dalam bentuk grafik dan peta tematik untuk menjawab tujuan penelitian pertama. Sedangkan analisis inferensia dalam penelitian ini dilakukan dengan menggunakan analisis regresi logistik biner yang menggunakan metode Firth dalam melakukan estimasi parameternya untuk menjawab tujuan penelitian kedua dan ketiga. Metode regresi logistik biner digunakan karena variabel respons dalam penelitian bersifat kategorik yang memiliki dua kategori, yaitu pernah mengalami kecelakaan sebagai kategori sukses $(\mathrm{Y}=1)$ dan tidak pernah mengalami kecelakaan sebagai kategori gagal $(\mathrm{Y}=0)$. Sedangkan metode estimasi parameter Firth digunakan dalam penelitian ini karena kategori sukses dalam variabel respons $(\mathrm{Y}=1)$ jumlahnya jauh lebih sedikit dibandingkan kategori gagal $(\mathrm{Y}=0)$, sebab kecelakaan lalu lintas merupakan kejadian langka. Tahap-tahap analisis inferensia dilakukan sebagai berikut:

1. Melakukan pembentukan model

2. Melakukan uji kesesuaian model menggunakan uji Hosmer-Lemeshow

3. Melakukan uji signifikansi penduga parameter secara simultan dengan uji likelihood ratio

4. Melakukan uji signifikansi penduga parameter secara parsial menggunakan uji Wald

5. Menginterpretasi nilai odds ratio

\section{HASIL DAN PEMBAHASAN}

\subsection{Gambaran Umum Karakteristik Komuter Pelajar Jabodetabek Tahun 2019}

Berdasarkan hasil pengolahan raw data hasil Survei Komuter Jabodetabek tahun 2019, diperkirakan terdapat 19 hingga 20 dari 100 komuter Jabodetabek yang merupakan komuter pelajar. Berdasarkan tempat tinggal, persentase komuter pelajar tertinggi berada di Kabupaten Bekasi, Kota Depok, dan Kabupaten Bogor seperti yang ditampilkan pada Gambar 2(a). Sedangkan berdasarkan tempat kegiatan, persentase komuter pelajar tertinggi berada di Kota Depok, Kota Bekasi, dan Kota Bogor yang ditampilkan pada Gambar 2(b).

Sementara itu, diperkirakan terdapat 6 hingga 7 dari 100 komuter pelajar Jabodetabek pernah mengalami kecelakaan lalu lintas. Berdasarkan tempat tinggal, persentase komuter pelajar yang pernah mengalami kecelakaan tertinggi berada di Kabupaten Bogor, Kota Jakarta Pusat, dan Kabupaten Bekasi seperti yang ditampilkan pada Gambar 3(a). Sedangkan berdasarkan tempat kegiatan, persentase komuter pelajar yang pernah mengalami kecelakaan tertinggi berada di wilayah Kota Bogor, Kota Tangerang Selatan, dan Kota Jakarta Utara seperti yang ditampikan pada Gambar 3(b). 


\section{Jurnal Matematika, Statistika \& Komputasi}

\section{Aprilia Lutviana Dewi, Budyanra}

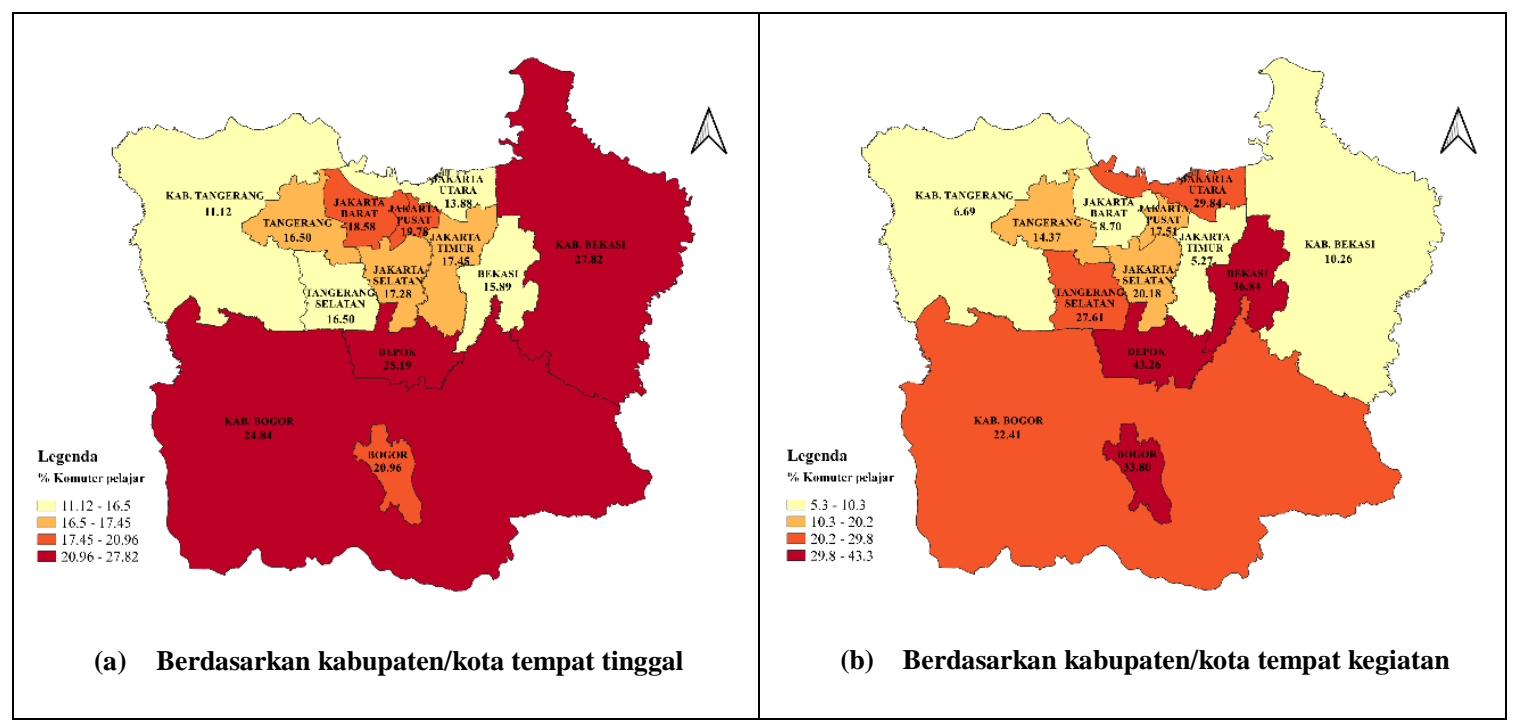

Gambar 2. Persentase komuter pelajar Jabodetabek berdasarkan kabupaten/kota

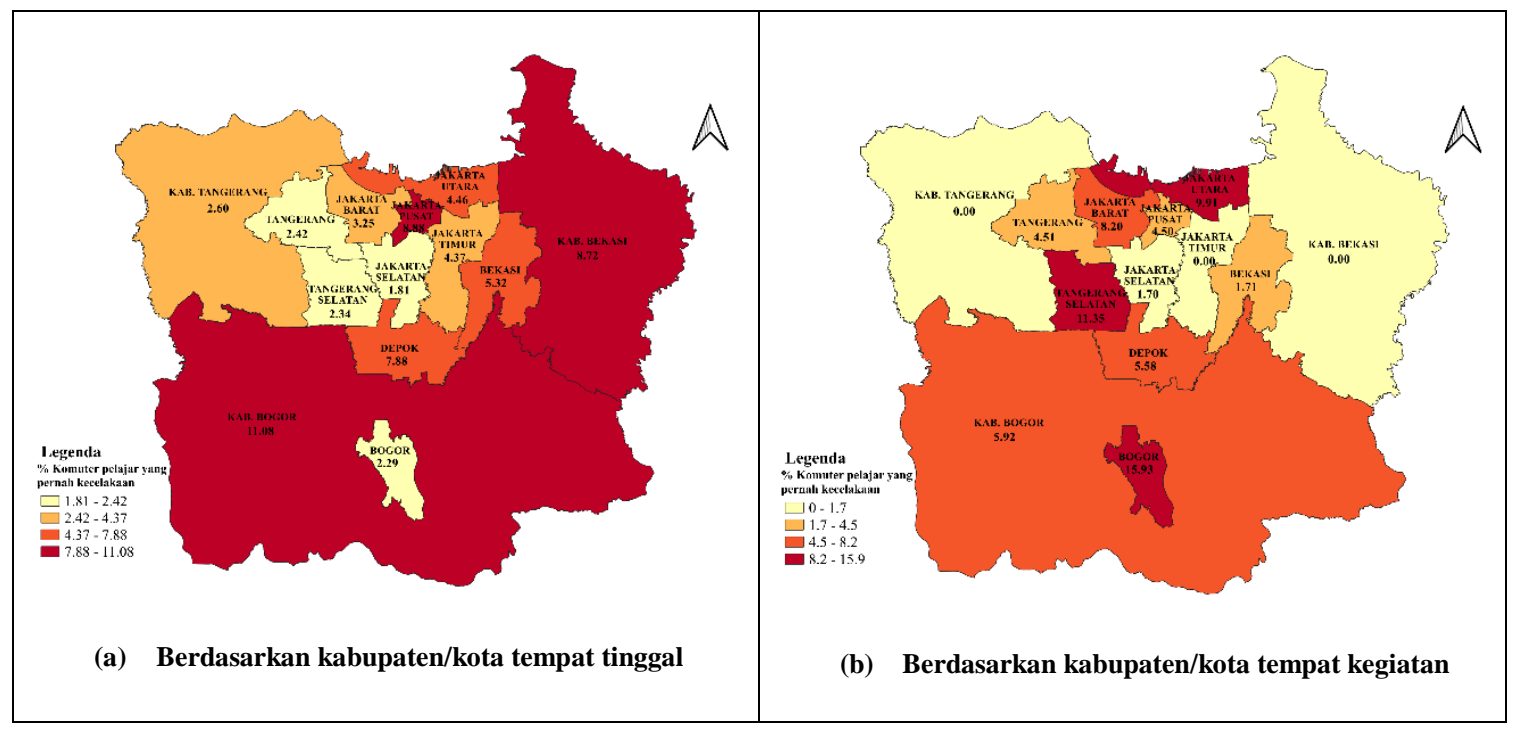

Gambar 3. Persentase komuter pelajar Jabodetabek yang pernah mengalami kecelakaan berdasarkan kabupaten/kota

Gambaran umum status kecelakaan menurut karakteristik komuter pelajar Jabodetabek disajikan dalam Tabel 1. Persentase komuter pelajar Jabodetabek yang pernah mengalami kecelakaan sebagian besar memiliki karakteristik seperti berumur 16 - 19 tahun, berjenis kelamin laki-laki, berpendidikan terakhir SMP ke bawah, menggunakan transportasi pribadi, bertempat tinggal di wilayah perdesaan, menempuh jarak perjalanan lebih dari $10 \mathrm{~km}$, dan berkegiatan di wilayah Bogor. 


\section{Jurnal Matematika, Statistika \& Komputasi}

\section{Aprilia Lutviana Dewi, Budyanra}

Tabel 1. Persentase komuter pelajar menurut variabel prediktor

\begin{tabular}{|c|c|c|c|c|c|}
\hline \multirow[t]{2}{*}{ No. } & \multirow[t]{2}{*}{ Variabel } & \multirow{2}{*}{$\begin{array}{c}\text { Kode } \\
\text { Dummy }\end{array}$} & \multirow{2}{*}{$\begin{array}{l}\text { Kategori } \\
\text { Variabel }\end{array}$} & \multicolumn{2}{|c|}{ Status Kecelakaan } \\
\hline & & & & Pernah & $\begin{array}{l}\text { Tidak } \\
\text { Pernah }\end{array}$ \\
\hline (1) & (2) & & (3) & (4) & $(5)$ \\
\hline \multirow[t]{3}{*}{1} & Umur komuter & 2 & $<16$ tahun & $5,51 \%$ & $95,45 \%$ \\
\hline & pelajar $\left(D_{1}\right)$ & 1 & $16-19$ tahun & $7,39 \%$ & $92,61 \%$ \\
\hline & & $0 *$ & $>19$ tahun & $6,22 \%$ & $93,78 \%$ \\
\hline \multirow[t]{2}{*}{2} & Jenis kelamin & 1 & Laki-laki & $9,28 \%$ & $90,72 \%$ \\
\hline & komuter pelajar $\left(D_{2}\right)$ & $0 *$ & Perempuan & $3,45 \%$ & $94,34 \%$ \\
\hline \multirow[t]{2}{*}{3} & Pendidikan terakhir & 1 & $\leq \mathrm{SMP}$ & $7,07 \%$ & $92,93 \%$ \\
\hline & komuter pelajar $\left(D_{3}\right)$ & $0 *$ & $>\mathrm{SMP}$ & $6,01 \%$ & $93,99 \%$ \\
\hline \multirow[t]{2}{*}{4} & Moda transportasi & 1 & Transportasi & $8,39 \%$ & $91,61 \%$ \\
\hline & komuter pelajar $\left(D_{4}\right)$ & $0 *$ & $\begin{array}{l}\text { pribadi } \\
\text { Transportasi } \\
\text { umum }\end{array}$ & $2,12 \%$ & $97,88 \%$ \\
\hline \multirow[t]{2}{*}{5} & Klasifikasi wilayah & 1 & Perdesaan & $42,72 \%$ & $57,28 \%$ \\
\hline & tempat tinggal $\left(D_{5}\right)$ & $0^{*}$ & Perkotaan & $6,04 \%$ & $93,96 \%$ \\
\hline \multirow[t]{2}{*}{6} & Jarak tempuh & 1 & $>10 \mathrm{~km}$ & $3,89 \%$ & $96,11 \%$ \\
\hline & komuter pelajar $\left(D_{6}\right)$ & $0 *$ & $\leq 10 \mathrm{~km}$ & $8,85 \%$ & $91,15 \%$ \\
\hline \multirow[t]{3}{*}{7} & Wilayah kegiatan & 2 & Jakarta & $5,98 \%$ & $94,02 \%$ \\
\hline & komuter pelajar $\left(D_{7}\right)$ & 1 & Bogor & $11,75 \%$ & $88,25 \%$ \\
\hline & & $0^{*}$ & Detabek & $5,01 \%$ & $94,99 \%$ \\
\hline
\end{tabular}

Keterangan: * merupakan kategori referensi.

\subsection{Variabel-Variabel yang Signifikan Memengaruhi Status Kecelakaan pada Komuter Pelajar Jabodetabek Tahun 2019}

Dalam penelitian ini, persamaan regresi logistik biner, seperti pada Persamaan (3), yang terbentuk dari proses pendugaan parameter menggunakan rumus Persamaan (7) adalah sebagai berikut:

$$
\begin{gathered}
\hat{g}(x)=-7,68+2,06 D_{11}+1,86 D_{12}+0,74 D_{2}+2,53 D_{3}+1,57 D_{4}+2,64 D_{5}+1,57 D_{6} \\
+1,09 D_{71}+0,13 D_{72}
\end{gathered}
$$

Keterangan:

$$
\begin{array}{ll}
D_{11} & \text { : dummy variabel umur komuter pelajar } 16-19 \text { tahun } \\
D_{12} & \text { : dummy variabel umur komuter pelajar }>19 \text { tahun } \\
D_{2} & \text { : dummy variabel jenis kelamin komuter pelajar } \\
D_{3} & \text { : dummy variabel pendidikan terakhir komuter pelajar } \\
D_{4} & \text { : dummy variabel moda transportasi komuter pelajar } \\
D_{5} & \text { : dummy variabel klasifikasi wilayah tempat tinggal } \\
D_{6} & \text { : dummy variabel jarak tempuh komuter pelajar } \\
D_{71} & \text { : dummy variabel wilayah kegiatan komuter pelajar Bogor } \\
D_{72} & \text { : dummy variabel wilayah kegiatan komuter pelajar Jakarta }
\end{array}
$$

\section{a) Hasil Uji Hosmer-Lemeshow}

Hasil uji kesesuaian model ditunjukkan pada Tabel 2. Uji ini dilakukan dengan membandingkan nilai statistik uji $\widehat{C}$ pada kolom (1) yang dihitung menggunakan rumus pada 


\section{Jurnal Matematika, Statistika \& Komputasi}

\section{Aprilia Lutviana Dewi, Budyanra}

Persamaan (8) dengan nilai statistik tabel pada kolom (3) atau dengan melihat hasil p-value pada kolom (4).

Tabel 2. Hasil uji Hosmer - Lemeshow pada $\alpha=5 \%$.

\begin{tabular}{cccc}
\hline$\widehat{\boldsymbol{C}}$ & $\boldsymbol{d f}$ & $\chi_{0,05(8)}^{2}$ & $\boldsymbol{p}$-value \\
\hline$(1)$ & $(2)$ & $(3)$ & $(4)$ \\
5,62 & 8 & 15,51 & 0,69 \\
\hline
\end{tabular}

Berdasarkan hasil yang ditunjukkan pada Tabel 2, dapat dilihat bahwa statistik uji bernilai 5,62 lebih kecil daripada 15,51 dan nilai $p$-value juga lebih besar daripada 0,05, sehingga diperoleh keputusan gagal tolak $H_{0}$. Artinya, model regresi logistik biner yang terbentuk sudah cocok untuk menjelaskan status kecelakaan pada komuter pelajar.

\section{b) Hasil Uji Likelihood Ratio}

Langkah selanjutnya yaitu melakukan uji signifikansi penduga parameter secara simultan. Hasil uji penduga parameter secara simultan ditunjukkan pada Tabel 3. Uji ini dilakukan dengan membandingkan nilai statistik uji $\mathrm{G}$ pada kolom (3) yang dihitung menggunakan rumus pada Persamaan (9) dengan nilai statistik tabel pada kolom (4).

Tabel 3. Hasil uji likelihood ratio pada $\alpha=5 \%$.

\begin{tabular}{cccc}
\hline $\boldsymbol{\operatorname { l n }}\left(\boldsymbol{L}_{0}\right)$ & $\boldsymbol{\operatorname { l n }}\left(\boldsymbol{L}_{\mathbf{1}}\right)$ & $\boldsymbol{G}$ & $\chi_{0,05(9)}^{2}$ \\
\hline$(1)$ & $(2)$ & $(3)$ & $(4)$ \\
$-184,05$ & $-156,01$ & 56,07 & 16,92 \\
\hline
\end{tabular}

Berdasarkan hasil yang ditunjukkan pada Tabel 3, dapat dilihat bahwa statistik uji G bernilai 56,07 lebih besar daripada 16,92, sehingga diperoleh keputusan tolak $H_{0}$. Artinya, minimal terdapat satu variabel prediktor yang berpengaruh signifikan terhadap status kecelakaan komuter pelajar Jabodetabek tahun 2019.

\section{c) Hasil Uji Wald}

Setelah melakukan uji penduga parameter secara simultan, selanjutnya dilakukan uji penduga parameter secara parsial. Hasil uji penduga parameter secara parsial ditunjukkan pada Tabel 4. Uji ini dilakukan dengan melihat nilai statistik uji W pada kolom (4) yang dihitung menggunakan rumus pada Persamaan (10) atau $p$-value pada kolom (5).

Berdasarkan nilai statistik uji W kolom (4) serta $p$-value pada kolom (5) pada Tabel 4, dapat dilihat bahwa seluruh variabel prediktor secara signifikan memengaruhi status kecelakaan komuter, kecuali variabel wilayah kegiatan Jakarta. Artinya, variabel umur, jenis kelamin, pendidikan terakhir, moda transportasi, klasifikasi wilayah tempat tinggal, jarak tempuh, dan wilayah kegiatan berpengaruh signifikan terhadap status kecelakaan komuter pelajar Jabodetabek tahun 2019 secara parsial, kecuali variabel wilayah kegiatan Jakarta.

Tabel 4. Hasil uji Wald pada $\alpha=5 \%$.

\begin{tabular}{|c|c|c|c|c|c|}
\hline Variabel & $\widetilde{\beta}$ & SE & $\mathbf{W}$ & p-value & $\operatorname{Exp}(\bar{\beta})$ \\
\hline (1) & (2) & (3) & (4) & (5) & (6) \\
\hline Intercept* & $-7,67$ & 1,06 & 52,34 & 0,00 & 0,001 \\
\hline
\end{tabular}




\section{Jumal Matematika, Statistika E Komputasi}

\section{Aprilia Lutviana Dewi, Budyanra}

\begin{tabular}{|c|c|c|c|c|c|}
\hline \multicolumn{6}{|c|}{ Umur Komuter Pelajar } \\
\hline$<16$ tahun $*$ & 1,86 & 0,83 & 5,02 & 0,02 & 6,39 \\
\hline $16-19$ tahun $*$ & 2,06 & 0,73 & 7,96 & 0,01 & 7,82 \\
\hline$>19$ tahun (reference) & & & & & \\
\hline \multicolumn{6}{|c|}{ Jenis Kelamin Komuter Pelajar } \\
\hline Laki-laki* & 0,74 & 0,33 & 4,93 & 0,03 & 2,09 \\
\hline \multicolumn{6}{|l|}{ Perempuan (reference) } \\
\hline \multicolumn{6}{|c|}{ Pendidikan Terakhir Komuter Pelajar } \\
\hline$\leq \mathrm{SMP} *$ & 2,53 & 0,75 & 11,38 & 0,00 & 12,57 \\
\hline > SMP (reference) & & & & & \\
\hline \multicolumn{6}{|c|}{ Moda Transportasi Komuter Pelajar } \\
\hline Transportasi pribadi* & 1,57 & 0,47 & 11,16 & 0,00 & 4,83 \\
\hline \multicolumn{6}{|c|}{ Transportasi umum (reference) } \\
\hline \multicolumn{6}{|c|}{ Klasifikasi Wilayah Tempat Tinggal } \\
\hline Perdesaan* & 2,64 & 0,88 & 9,00 & 0,00 & 14,03 \\
\hline \multicolumn{6}{|l|}{ Perkotaan (reference) } \\
\hline \multicolumn{6}{|c|}{ Jarak Tempuh Komuter Pelajar } \\
\hline$>10 \mathrm{~km} *$ & 1,48 & 0,38 & 15,16 & 0,00 & 4,39 \\
\hline \multicolumn{6}{|l|}{$\leq 10 \mathrm{~km}($ reference $)$} \\
\hline \multicolumn{6}{|c|}{ Wilayah Kegiatan Komuter Pelajar } \\
\hline Jakarta & 0,13 & 0,36 & 0,13 & 0,73 & 1,13 \\
\hline Bogor* & 1,09 & 0,51 & 4,57 & 0,03 & 2,98 \\
\hline Detabek (reference) & & & & & \\
\hline
\end{tabular}

Keterangan: * signifikan pada tingkat signifikansi $5 \%$.

\subsection{Kecenderungan Variabel-Variabel yang Signifikan Memengaruhi Status Kecelakaan pada Komuter Pelajar Jabodetabek Tahun 2019}

Setelah melakukan uji penduga parameter secara parsial, diperoleh nilai odds ratio dari masing-masing variabel prediktor pada Tabel 4.4 kolom (6) yang dihitung menggunakan rumus pada Persamaan (11). Interpretasi odds ratio dari masing-masing variabel prediktor dijelaskan sebagai berikut:

\section{Umur Komuter Pelajar}

Variabel umur kategori 16 - 19 tahun memiliki odds ratio sebesar 7,82. Artinya, komuter pelajar Jabodetabek berumur 16 - 19 tahun memiliki kecenderungan sebesar 7,82 kali untuk mengalami kecelakaan lalu lintas dibandingkan komuter pelajar berumur lebih dari 19 tahun dengan mengasumsikan variabel prediktor lain konstan. Sedangkan variabel umur kategori kurang dari 16 tahun memiliki odds ratio sebesar 6,39. Artinya, komuter pelajar Jabodetabek berumur kurang dari 16 tahun memiliki kecenderungan 6,39 kali untuk mengalami kecelakaan lalu lintas dibandingkan komuter pelajar berumur lebih dari 19 tahun dengan mengasumsikan variabel prediktor lain konstan. Hasil ini sejalan dengan hasil penelitian terdahulu bahwa pengendara berumur 16 - 19 tahun memiliki kecenderungan lebih besar untuk mengalami kecelakaan lalu lintas dibandingkan kelompok umur lainnya [25]. Ini disebabkan karena kelompok umur tersebut didominasi oleh pelajar SMP dan SMA yang baru mulai mengendarai motor dan belum memiliki Surat Izin Mengemudi (SIM).

2. Jenis Kelamin Komuter Pelajar

Variabel jenis kelamin memiliki odds ratio sebesar 2,09. Artinya, komuter pelajar Jabodetabek berjenis kelamin laki-laki memiliki kecenderungan sebesar 2,09 kali untuk 


\section{Jumal Matematika, Statistika E Komputasi Aprilia Lutviana Dewi, Budyanra}

mengalami kecelakaan lalu lintas dibandingkan komuter pelajar berjenis kelamin perempuan dengan mengasumsikan variabel prediktor lain konstan. Hasil ini sejalan dengan hasil penelitian terdahulu bahwa laki-laki memiliki kecenderungan lebih besar untuk mengalami kecelakaan lalu lintas dibandingkan perempuan [25]. Ini disebabkan karena laki-laki memiliki perilaku berkendara yang lebih beresiko, seperti menggunakan kecepatan tinggi, jarang menggunakan pelindung berkendara, berkendara secara berdekatan dengan kendaraan lain, dan perilaku menerobos lalu lintas.

\section{Pendidikan Terakhir Komuter Pelajar}

Variabel pendidikan terakhir memiiki odds ratio sebesar 12,57. Artinya, komuter pelajar Jabodetabek dengan pendidikan terakhir SMP ke bawah memiliki kecenderungan sebesar 12,57 kali untuk mengalami kecelakaan lalu lintas dibandingkan komuter pelajar dengan pendidikan terakhir lebih dari SMP dengan mengasumsikan variabel prediktor lain konstan. Hasil ini sejalan dengan hasil penelitian terdahulu bahwa pengendara dengan pendidikan SMP ke bawah memiliki kecenderungan lebih besar untuk mengalami kecelakaan lalu lintas dibandingkan pengendara dengan pendidikan di atas SMP [26]. Ini disebabkan karena kualitas pengetahuan dan pemahaman mengenai perilaku berkendara pada pengendara dengan pendidikan SMP ke bawah masih lebih minim dibandingkan pengendara dengan pendidikan di atas SMP, sehingga memiliki resiko mengalami kecelakaan lalu lintas yang tinggi.

\section{Moda Transportasi Komuter Pelajar}

Variabel moda transportasi memiliki odds ratio sebesar 4,83. Artinya, komuter pelajar Jabodetabek yang menggunakan transportasi pribadi memiliki kecenderungan sebesar 4,83 kali untuk mengalami kecelakaan lalu lintas dibandingkan komuter pelajar yang menggunakan transportasi umum dengan mengasumsikan variabel prediktor lain konstan. Hasil ini sejalan dengan hasil penelitian terdahulu bahwa pengguna transportasi pribadi memiliki kecenderungan lebih besar untuk mengalami kecelakaan lalu lintas dibandingkan pengguna transportasi umum [21]. Ini disebabkan karena adanya kecenderungan yang lebih tinggi untuk melakukan perilaku berkendara yang berbahaya saat mengendarai transportasi pribadi dibandingkan saat menggunakan transportasi umum.

\section{Klasifikasi Wilayah Tempat Tinggal}

Variabel klasifikasi wilayah tempat tinggal memiliki odds ratio sebesar 14,03. Artinya, komuter pelajar Jabodetabek yang tinggal di wilayah perdesaan memiliki kecenderungan sebesar 14,03 kali untuk mengalami kecelakaan lalu lintas dibandingkan komuter pelajar yang tinggal di wilayah perkotaan dengan mengasumsikan variabel prediktor lain konstan. Hasil ini sejalan dengan hasil penelitian terdahulu bahwa pengendara yang tinggal di wilayah perdesaan memiliki kecenderungan lebih besar untuk mengalami kecelakaan lalu lintas dibandingkan pengendara yang tinggal di wilayah perkotaan [37]. Ini disebabkan karena pengendara yang tinggal di wilayah perdesaan memiliki kecenderungan tinggi untuk berkendara dengan kecepatan tinggi akibat kondisi jalan yang lebih sepi dibandingkan di wilayah perkotaan.

\section{Jarak Tempuh Komuter Pelajar}

Variabel jarak memiliki odds ratio sebesar 4,39. Artinya, komuter pelajar Jabodetabek yang menempuh jarak di atas $10 \mathrm{~km}$ memiliki kecenderungan sebesar 4,39 kali untuk mengalami kecelakaan lalu lintas dibandingkan komuter pelajar yang menempuh jarak $10 \mathrm{~km}$ ke bawah dengan mengasumsikan variabel prediktor lain konstan. Hasil ini sejalan dengan hasil penelitian terdahulu bahwa pengendara yang menempuh jarak lebih dari $10 \mathrm{~km}$ memiliki kecenderungan lebih besar untuk mengalami kecelakaan lalu lintas dibandingkan pengendara yang menempuh jarak $10 \mathrm{~km}$ ke bawah [3]. Ini disebabkan karena jarak $10 \mathrm{~km}$ merupakan batas maksimal yang 


\section{Jurnal Matematika, Statistika \& Komputasi} Aprilia Lutviana Dewi, Budyanra

ideal bagi pengguna jalan tanpa merasa kelelahan, sehingga pengguna jalan akan berkurang fokusnya akibat kelelahan saat menempuh jarak lebih dari $10 \mathrm{~km}[10]$.

7. Wilayah Kegiatan Komuter Pelajar

Variabel wilayah kegiatan kategori Bogor memiliki odds ratio sebesar 2,98. Artinya, komuter pelajar Jabodetabek yang berkegiatan di wilayah Bogor memiliki kecenderungan sebesar 2,98 kali untuk mengalami kecelakaan lalu lintas dibandingkan komuter pelajar yang berkegiatan di wilayah Detabek dengan mengasumsikan variabel prediktor lain konstan. Ini dapat disebabkan karena wilayah Bogor memiliki karakteristik wilayah yang beresiko tinggi terhadap kecelakaan, yaitu memiliki intensitas hujan yang tinggi dan persentase jalan dengan kondisi kurang baik yang lebih tinggi dibandingkan wilayah Jabodetabek lainnya $[8,28]$. Menurut penelitian terdahulu, karakteristik wilayah yang demikian dapat meningkatkan angka kecelakaan pada wilayah tersebut [42].

\section{KESIMPULAN}

Berdasarkan hasil analisis dan pembahasan di atas, maka diperoleh kesimpulan sebagai berikut:

1. Pada tahun 2019, diperkirakan terdapat 19 hingga 20 dari 100 komuter Jabodetabek yang merupakan komuter pelajar. Sementara itu, diperkirakan terdapat 6 hingga 7 dari 100 komuter pelajar Jabodetabek pernah mengalami kecelakaan lalu lintas. Persentase komuter pelajar Jabodetabek yang pernah mengalami kecelakaan sebagian besar memiliki karakteristik seperti berumur 16 - 19 tahun, berjenis kelamin laki-laki, memiliki pendidikan terakhir SMP ke bawah, menggunakan transportasi pribadi, bertempat tinggal di wilayah perdesaan, menempuh jarak perjalanan lebih dari $10 \mathrm{~km}$, dan berkegiatan di wilayah Bogor.

2. Variabel umur komuter pelajar, jenis kelamin komuter pelajar, pendidikan terakhir komuter pelajar, moda transportasi komuter pelajar, klasifikasi wilayah tempat tinggal, jarak tempuh komuter pelajar, dan wilayah kegiatan komuter pelajar signifikan memengaruhi status kecelakaan pada komuter pelajar Jabodetabek tahun 2019.

3. Komuter pelajar Jabodetabek berumur $16-19$ tahun, berjenis kelamin laki-laki, memiliki pendidikan terakhir SMP ke bawah, menggunakan transportasi pribadi, bertempat tinggal di wilayah perdesaan, menempuh jarak perjalanan lebih dari $10 \mathrm{~km}$, dan berkegiatan di wilayah Bogor memiliki kecenderungan lebih tinggi untuk mengalami kecelakaan lalu lintas. Variabel klasifikasi wilayah tempat tinggal dan pendidikan terakhir memiliki kecenderungan paling tinggi untuk mengalami kecelakaan lalu lintas.

\section{DAFTAR PUSTAKA}

[1] Ainy, E., Khorshidi, A., Monfared, A. B., Soori, H., Haddadi, M., 2016. Epidemiological Pattern of Road Traffic Injuries among Occupants Vehicles in 2012. Journal of transportation technologies, Vol. 6, No. 5, pp. 277-285.

[2] Agresti, A., 2013. An Introduction to Categorical Data Analysis, Third Edition. John Wiley \& Sons Inc., New Jersey.

[3] Arifin, M. Z., Ambarwati, L., Pratama, N. B., Danaswari, V., 2021. Model Peluang Kecelakaan Pengguna Sepeda Motor Dengan Metode Regresi Logistik. Jurnal Rekayasa Sipil dan Lingkungan Universitas Jember, Vol. 4, No. 2, pp. 164-170.

[4] ASEAN Stats Data Portal, 2017. Number of Traffic Accident Casualties (Injuries) by Road. 2017. ASEAN. https://data.aseanstats.org/indicator/ASE.TRP.ROD.E.031. [12 November 2020] 


\section{Jurnal Matematika, Statistika \& Komputasi}

\section{Aprilia Lutviana Dewi, Budyanra}

[5] Badan Pusat Statistik, 2008. Analisis Mobilitas Tenaga Kerja Hasil Sakernas 2008. Badan Pusat Statistik, Jakarta.

[6] Badan Pusat Statistik, 2019. Statistik Komuter Jabodetabek: Hasil Survei Komuter Jabodetabek 2019. Badan Pusat Statistik, Jakarta.

[7] Badan Pusat Statistik Provinsi Banten, 2020. Provinsi Banten dalam Angka 2020. Badan Pusat Statistik Provinsi Banten, Serang.

[8] Badan Pusat Statistik Provinsi Jawa Barat, 2020. Provinsi Jawa Barat dalam Angka 2020. Badan Pusat Statistik Provinsi Jawa Barat, Bandung.

[9] Bener, A., Burgut, H. R., Sidahmed, H., AlBuz, R., Sanya, R., \& Khan, W. A., 2009. Road traffic injuries and risk factors. Californian Journal of Health Promotion, Vol. 7, No. 2, pp. 92-101.

[10] Choi, J., Lee, K., Kim, H., An, S., \& Nam, D., 2020. Classification of InterUrban Highway Drivers' Resting Behavior for Advanced Driver-Assistance System Technologies Using Vehicle Trajectory Data from Car Navigation Systems. Sustainability, Vol. 12, No. 15, pp. 5936.

[11] Eurostat. 2018. Road Safety Statistics - Characteristics at National and Regional Level. Eurostat Statistics Explained. https://ec.europa.eu/eurostat/statisticsexplained/index.php?title=Road_ safety_statistics__characteristics_at_national_and_regional_level\# Regional_risk_variation. [3 Juni 2021]

[12] Firth, D. 1993. Bias Reduction of Maximum Likelihood Estimates. Biometrika, Vol. 80, No. 1, pp. 27-38.

[13] Gigy, D. P. D., Setyobudi, A., \& Tira, D. S. 2019. Faktor-Faktor yang Berhubungan dengan Risiko Kecelakaan Lalu Lintas pada Siswa SMA di Kota Kupang Tahun 2019. Lontar: Journal of Community Health Universitas Nusa Cendana, Vol. 1, No. 4, pp. 140-146.

[14] Haddon, W. (1980). Advances in The Epidemiology of Injuries as A Basis For Public Policy. Public Health Reports, Vol. 95, No. 5, pp. 411-421.

[15] Helmi., 2019. Pelajar dan Mahasiswa Paling Rawan Menjadi Korban Laka Lantas. Bisnis News. https://bisnisnews.id/detail/berita/pelajar-dan-mahasiswa-paling-rawanmenjadi-korban-laka-lantas. [1 Oktober 2020]

[16] Hosmer, D. W. \& Lemeshow, S., 2000. Applied Logistic Regression, Second Edition. John Wiley \& Sons Inc., New Jersey.

[17] Hugo, G. J., 1975. Population Mobility in West Java, Indonesia [Tesis]. Research School of Social Sciences, Australian National University, Canberra.

[18] Karabon, P., 2020. Rare events or non-convergence with binary outcome? The power of Firth regression in PROC LOGISTIC. Paper presented at SAS Global Forum 2020.

[19] Kemkominfo, 2017. Rata-rata Tiga Orang Meninggal Setiap Jam Akibat Kecelakaan Jalan. Kementerian Komunikasi dan Informasi. https://kominfo.go.id/index.php/content/detail/10368/rata-rata-tiga-orang-meninggal-setiapjam-akibat-kecelakaan-jalan/0/artikel_gpr. [27 January 2021]

[20] King, G., \& Zeng, L., 2001. Logistic Regression in Rare Events Data. Political Analysis, Vol. 9, No. 2, 137-163.

[21] Litman, T., 2016. The Hidden Traffic Safety Solution: Public Transportation. American Public Transportation Association, Washington DC.

[22] Litman, T., \& Fitzroy, S., 2018. Safe Travels: Evaluating Transportation Demand Management Traffic Safety Impacts. Victoria Transport Policy Institute, Victoria.

[23] Mantra, I. B., 2003. Demografi Umum, Second Edition. Pustaka, Yogyakarta.

[24] Marsaid, M., Hidayat, M., \& Ahsan, A., 2013. Faktor yang Berhubungan dengan Kejadian Kecelakaan Lalu Lintas pada Pengendara Sepeda Motor di Wilayah Polres Kabupaten 


\section{Jumal Matematika, Statistika E Komputasi Aprilia Lutviana Dewi, Budyanra}

Malang. Jurnal Ilmu Keperawatan: Journal of Nursing Science Universitas Brawijaya, Vol. 1, No. 2, pp. 98-112.

[25] Massie, D. L., \& Campbell, K. L., 1993. Analysis of Accident Rates by Age, Gender, and Time of Day Based on the 1990 Nationwide Personal Transportation Survey. Transportation Research Institute, University of Michigan, Michigan.

[26] Miranti, M., Rumlawang, F. Y., \& Kondolembang, F., 2019. Pemodelan Faktor-Faktor Penyebab Keparahan Korban Kecelakaan Lalu Lintas di Kota Ambon dengan Menggunakan Model Regresi Logistik Multinomial. VARIANCE: Journal of Statistics and Its Applications, Vol. 1, No. 1, pp. 17-26.

[27] Peraturan Presiden Nomor 54 Tahun 2008, 2008. Penataan Ruang Kawasan Jakarta, Kota Bogor, Kota Depok, Kota Tangerang, Kota Bekasi, Puncak, Cianjur. Jakarta.

[28] Pojok Kota Bogor, 2021. Inilah Alasan Kenapa Kota Bogor Disebut Kota Hujan. Jaringan Pemberitahuan Nusantara Negeriku. https://www.jpnn.com/news/inilah-alasan-kenapa-Kota Bogor-disebut-kota-hujan. [3 Juni 2021]

[29] Pratiwi, Y. Y., \& Siahaan, F. C., 2017. Accident Amo ng Children in Indonesia Urban Areas. Jurnal Himpunan Pengembangan Jalan Indonesia, Vol. 3, No. 2, pp. 79-92.

[30] Pusat Data dan Informasi, 2018. Informasi Statistik Pekerjaan Umum dan Perumahan Rakyat. Pusat Data dan Informasi, Jakarta.

[31] Rahmatulloh, R., 2018. Dinamika Kependudukan di Ibukota Jakarta (Deskripsi Perkembangan Kuantitas, Kualitas dan Kesejahteraan Penduduk di DKI Jakarta). Genta Mulia: Jurnal Ilmiah Pendidikan, Vol. 8, No. 2, pp. 54-67.

[32] Ratnasari, F., Kumaat, L. T., \& Mulyadi, N., 2014. Hubungan Karakteristik Remaja Dengan Kejadian Kecelakaan Lalu Lintas Pada Komunitas Motor Sulut King Community (SKC) Manado. Jurnal Keperawatan Universitas Sam Ratulangi, Vol.2, No. 2.

[33] Sami, A., Najafi, A., Yamini, N., Moafian, G., Aghabeigi, M. R., Lankarani, K. B., \& Heydari, S. T., 2013. Educational Level and Age as Contributing Factors to Road Traffic Accidents. Chinese Journal of Traumatology, Vol. 16, No. 5, pp. 281285.

[34] Samudra, M. A., 2020. Gawat! Angka Kecelakaan di Indonesia Makin Tinggi, Didominasi oleh Pelajar dan Mahasiswa. GridOto. https://www.gridoto.com/read/222345161/gawatangka-kecelakaan-di-indonesia-makin-tinggi-didominasi-oleh-pelajar-dan-mahasiswa. $\quad[12$ November 2020]

[35] Setyowati, D. L., Firdaus, A. R., \& Rohmah, N., 2018. Faktor penyebab kecelakaan lalu lintas pada siswa sekolah menengah atas di Kota Samarinda. The Indonesian Journal of Occupational Safety and Health, Vol. 7, No. 3, pp. 329-338.

[36] Soehodho, S., 2017. Public Transportation Development and Traffic Accident Prevention in Indonesia. IATSS Research, Vol. 40, No. 2, pp. 76-80.

[37] Tziotis, M., Roper, P., Edmonston, C., \& Sheehan, M. C., 2006. Road Safety In Rural and Remote Areas of Australia. Austroads, Sydney.

[38] Undang-Undang Republik Indonesia Nomor 22 Tahun 2009, 2009. Lalu Lintas dan Angkutan Jalan. 22 Juni 2009. Lembaran Negara Republik Indonesia Tahun 2009 Nomor 96. Jakarta.

[39] Warsida, R. Y., Adioetomo, S. M., \& Pardede, E., 2013. Pengaruh Variabel SosioDemografis Terhadap Mobilitas Ulang-Alik di Jabodetabek. Jurnal Ekonomi dan Pembangunan Indonesia, Vol.13, No. 2, pp. 159-176.

[40] World Health Organization., 2014. Injuries and Violence: The Facts 2014. World Health Organization, Geneva. 


\section{Jurnal Matematika, Statistika \& Komputasi}

Aprilia Lutviana Dewi, Budyanra

[41] World Health Organization, 2018. Global Status Report on Road Safety. World Health Organization, Geneva.

[42] Zegeer, C. V., Stewart, R., Council, F., \& Neuman, T. R, 1994. Accident Relationships of Roadway Width on Low-Volume Roads. Transportation Research Record, pp. 160-160. 